\title{
September 2013 Arizona Thoracic Society Notes
}

The September Arizona Thoracic Society meeting was held on Wednesday, 9/25/2013 at Shea Hospital beginning at 6:30 PM. There were 13 in attendance representing the pulmonary, critical care, sleep, and pathology communities.

After a brief discussion, Gerry Swartzberg was selected as Arizona's 2014 nominee for Clinician of the Year.

There was 1 case presented:

Dr. Thomas Colby, pulmonary pathologist from Mayo Clinic Arizona, presented the case of a 67 year old woman with multiple pulmonary nodules. The largest was $1.2 \mathrm{~cm} \mathrm{CT} \mathrm{scan.} \mathrm{She} \mathrm{had} \mathrm{a} \mathrm{fine} \mathrm{needle} \mathrm{aspiration} \mathrm{of} \mathrm{one} \mathrm{of} \mathrm{the} \mathrm{nodules.} \mathrm{The}$ pathology revealed spindle-shaped cells which were synaptophysin + (also known as the major synaptic vesicle protein p38). Synaptophysin marks neuroendocrine tissue and on this basis the patient was diagnosed with multiple carcinoid tumors. Aguayo et al. (1) described six patients with diffuse hyperplasia and dysplasia of pulmonary neuroendocrine cells, multiple carcinoid tumorlets, and peribronchiolar fibrosis obliterating small airways. Miller and Müller (2) described a series of 25 patients that were mostly women. Eight had obliterative bronchiolitis. Many questions arose including PET positivity (variable), endobronchial spread (unknown), use of somatostatin receptor scintigraphy (unknown).

There being no further business the meeting was adjourned at about 7:30 PM. The next meeting is scheduled for Wednesday, October 23, 6:30 PM in Phoenix at Scottsdale Shea Hospital.

Richard A. Robbins, M.D.

\section{References}

1. Aguayo SM, Miller YE, Waldron JA Jr, Bogin RM, Sunday ME, Staton GW Jr, Beam WR, King TE Jr. Brief report: idiopathic diffuse hyperplasia of pulmonary neuroendocrine cells and airways disease. N Engl J Med. 1992;327(18):1285-8. [CrossRef] [PubMed]

2. Miller RR, Müller NL. Neuroendocrine cell hyperplasia and obliterative bronchiolitis in patients with peripheral carcinoid tumors. Am J Surg Pathol. 1995;19(6):653-8. [CrossRef] [PubMed] 